\title{
Metaheuristic optimization of predictive torque control for induction motor control
}

\section{Asenkron motor kontrolü için öngörůllü moment kontrolünün metasezgisel optimizasyonu}

\author{
Aycan Gürel ${ }^{1}$ (D), Emrah Zerdali2,*' \\ ${ }^{1}$ Niğde Ömer Halisdemir University, Department of Electrical and Electronics Engineering, 51200, Niğde Turkey \\ ${ }^{2}$ Ege University, Department of Electrical and Electronics Engineering, 35100, Izmir Turkey
}

\begin{abstract}
Predictive torque control (PTC) is a high-performance control method of induction motors (IMs), which is still open to research. It provides many advantages over mature control techniques, such as straightforward implementation, the ability to handle nonlinearities, easy inclusion of additional control objectives, and modulatorfree structure. However, it has problems with the selection of weighting factors (WFs) involved in the cost function in PTC. In conventional PTC, these WFs are generally selected by the trial-and-error method. Also, a few studies optimize these WFs with a multi-objective optimization algorithm using both torque and flux errors. In this paper, the WF associated with the flux component is optimized by a genetic algorithm over the speed errors only. The optimized PTC is verified by simulation studies considering different operating conditions. Finally, good control performance has been achieved.
\end{abstract}

Keywords: Induction motor, Predictive torque control, Metaheuristic optimization

\section{Introduction}

Nowadays, the importance of electrical machines is increasing day by day due to the increase in electrification and induction motor (IM) is one of the most widely used energy conversion equipment. Therefore, high-performance control of IMs is a key point for the quality of energy conversion. However, highly nonlinear structure of IM with time-varying parameters and unknown inputs complicates the control of these motors; hence, advanced control techniques are needed [1,2]. Predictive torque control (PTC), which is a model predictive control strategy, is a powerful candidate due to its advantages such as straightforward implementation, the ability to handle nonlinearities, easy inclusion of additional control objectives, modulator free structure, etc [3, 4].

Despite all the advantages mentioned above, PTC has problems with the weighting factors (WFs) selection, variable switching frequency, torque ripples, parameter dependency; therefore, it is still open to research [1]. The most effective is strictly related to the choice of the WFs as
Özet

Öngörülü moment kontrolü (ÖMK), asenkron motorların (ASM'lerin) hala araştırmaya açık olan yüksek başarımlı kontrol yöntemlerinden biridir. Olgun kontrol tekniklerine kıyasla basit uygulama, doğrusal olmayan durumlarla başa çıkma yeteneği, ek kontrol hedeflerinin kolay dahil edilmesi ve modülatör içermeyen yapı vb. birçok üstünlük sağlamaktadır. Ancak, ÖMK maliyet fonksiyonunda yer alan ağırlıklandırma faktörlerinin (AF'lerin) seçimi ile ilgili sorunlara sahiptir. Geleneksel ÖMK'de bu AF'ler genellikle deneme-yanılma yöntemiyle seçilmektedir. Ayrıca, birkaç çalışma bu AF'leri hem moment hem de akı hatalarını kullanarak çok-amaçlı bir optimizasyon algoritması ile optimize eder. Bu çalışmada, akı bileşeniyle ilişkili AF, yalnızca hız hataları üzerinden bir genetik algoritma ile optimize edilmiștir. Optimize edilmiş ÖMK, farklı çalışma koşulları dikkate alınarak benzetim çalışmaları ile doğrulanmıştır. Son olarak, iyi bir kontrol performansı elde edilmiştir.

Anahtar kelimeler: Asenkron motor, Öngörülü moment kontrolü, Metasezgisel optimizasyon

it directly affects its control performance [5]. In conventional PTC, these WFs are determined by a time-consuming trialand-error method. To deal with this problem, different methods have been reported in the literature. The solutions can be divided into two main categories: WF selection methods [6-8] and WF elimination methods [9-15]. Considering the WF selection methods, one is meta-heuristic optimization of the WFs and a very limited number of studies optimizing the weighting factors have been addressed [6-8]. A multiobjective genetic algorithm (GA) is used by Guazzelli et al. [6] for the optimization of WFs and the results obtained are discussed comparatively. However, no selection method is proposed to choose one of the Pareto front solutions. To select one, Arshad et al. [7] use the TOPSIS algorithm. Unlike the other offline optimization methods, Davari at al. [8] use a simulated annealing (SA) algorithm online to optimize the WF associated with flux error. In the cost function of the SA, both torque and flux errors are used to create a single cost function called the scalarization method. This method has its drawback as stated

\footnotetext{
* Sorumlu yazar / Corresponding author, e-posta / e-mail: emrah.zerdali @ ege.edu.tr (E. Zerdali)

Geliş / Recieved: 11.07.2021 Kabul / Accepted: 19.08.2021 Yayımlanma / Published: 14.01.2022

doi: 10.28948/ngmuh.969734
} 
by [16]. All previous papers manage this optimization problem from a multi-objective perspective so far.

In this paper, the WF associated with the flux component is optimized by a GA over speed errors only. Contrary to the current literature that treats WF optimization as a multiobjective optimization problem, only the use of speed errors allows the optimization problem to be simplified. The reason for using a GA is that it is a mature method used in the optimization of different engineering problems and allows comparison with previous WF optimization studies in [6] and [7]. To show the effectiveness of the proposed method, the control performance of optimized PTC has been verified by simulation studies.

The rest of this paper is as follows. Section 2 gives the details of the PTC strategy for IM control. Section 3 introduces the optimization of the PTC. Section 4 presents the simulation results, followed by the conclusion in Section 5 .

\section{Predictive torque control of induction motor}

In this section, firstly, the mathematical model of an IM fed by a two-level voltage source inverter (2L-VSI) is given. Next, the PTC strategy for IM control is addressed in detail.

\subsection{Mathematical model of induction motor}

The mathematical model of IM can be defined as follows:

$$
\begin{gathered}
\boldsymbol{v}_{s}=R_{s} \boldsymbol{i}_{s}+\frac{\mathrm{d} \boldsymbol{\psi}_{s}}{\mathrm{~d} t} \\
0=R_{r} \boldsymbol{i}_{r}+\frac{\mathrm{d} \boldsymbol{\psi}_{r}}{\mathrm{~d} t}-j \omega_{r} \boldsymbol{\psi}_{r} \\
\boldsymbol{\psi}_{s}=L_{s} \boldsymbol{i}_{s}+L_{m} \boldsymbol{i}_{r} \\
\boldsymbol{\psi}_{r}=L_{m} \boldsymbol{i}_{s}+L_{r} \boldsymbol{i}_{r} \\
\tau_{e}=\frac{3}{2} p_{p} \Im m\left(\boldsymbol{\psi}_{s} \boldsymbol{i}_{s}\right) \\
\frac{\mathrm{d} \omega_{m}}{\mathrm{~d} t}=\frac{1}{J_{t}}\left(\tau_{e}-\tau_{l}\right)
\end{gathered}
$$

where $\boldsymbol{v}_{s}=v_{s \alpha}+j v_{s \beta}$ is the voltage vector; $\boldsymbol{i}_{s}=i_{s \alpha}+j i_{s \beta}$ and $\boldsymbol{i}_{r}=i_{r \alpha}+j i_{r \beta}$ are the stator and rotor current vectors, respectively; $\boldsymbol{\psi}_{s}=\psi_{s \alpha}+j \psi_{s \beta}$ and $\boldsymbol{\psi}_{r}=\psi_{r \alpha}+j \psi_{r \beta}$ are the stator and rotor flux vectors; $R_{s}$ and $R_{r}$ are the stator and rotor resistances, respectively; $L_{s}, L_{r}$, and $L_{m}$ are the stator, rotor, and mutual inductances, respectively; $\omega_{r}$ and $\omega_{m}$ are the rotor electrical and mechanical speeds, respectively; $\tau_{e}$ and $\tau_{l}$ are the electromagnetic torque and load torque, respectively; $p_{p}$ is the pole pairs; $J_{t}$ is the total inertia of the mechanical system. $\mathfrak{I} m$ refers to the imaginary part of a complex number.

In case the stator terminals of an IM are connected to a 2L-VSI shown in Figure 1a, stator voltage vectors can be calculated as

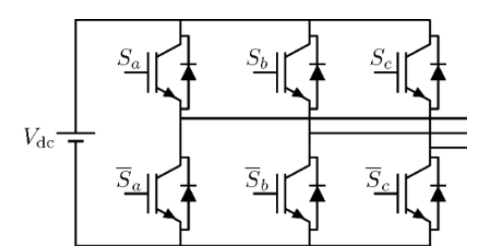

(a)

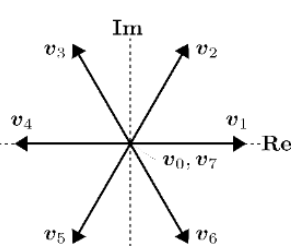

(b)
Figure 1. 2L-VSI (a) Inverter topology (b) Possible voltage vectors

$$
\boldsymbol{v}_{s}=\frac{2}{3} V_{\mathrm{dc}}\left(S_{a}+a S_{b}+a^{2} S_{c}\right)
$$

where $V_{\mathrm{dc}}$ is the dc-link voltage, $S_{x} \in\left\{S_{a}, S_{b}, S_{c}\right\}$ is the switching state of the upper switch on each leg, $a=e^{j 2 \pi / 3}$. Considering the eight possible switching combinations, seven different voltage vectors shown in Figure $1 \mathrm{~b}$ can be generated.

\subsection{PTC-based IM drive}

The block diagram of the PTC-based IM drive is shown in Figure 2. In this control technique, the optimal voltage vector for the next time step $k+1$ is chosen by using discrete-time IM model and a predefined cost function. For this purpose, the stator fluxes $\left(\boldsymbol{\psi}_{S}^{p}\right)$ and currents $\left(\boldsymbol{i}_{S}^{p}\right)$ can be predicted with the help of the discrete IM model for each voltage vector shown in Figure 1b. Next, the predicted electromagnetic torque $\left(\tau_{e}^{p}\right)$ can be calculated using these predicted quantities. Finally, optimal voltage vector is selected that minimizes the predefined cost function.

In order to predict the $\boldsymbol{\psi}_{s}^{p}$ and $\boldsymbol{i}_{s}^{p}$, rotor $\left(\boldsymbol{\psi}_{r}\right)$ and stator $\left(\boldsymbol{\psi}_{s}\right)$ fluxes are needed. The $\boldsymbol{\psi}_{r}$ can be estimated by the rotor current model of IM and then $\boldsymbol{\psi}_{s}$ can be calculated by using estimated $\boldsymbol{\psi}_{r}$ as given below.

$$
\begin{gathered}
\widehat{\boldsymbol{\psi}}_{r, k}=\widehat{\boldsymbol{\psi}}_{r, k-1}+T\left(R_{r} k_{r} \boldsymbol{i}_{s, k}-\left(\frac{1}{T_{r}}-j \omega_{r, k}\right) \widehat{\boldsymbol{\psi}}_{r, k-1}\right) \\
\widehat{\boldsymbol{\psi}}_{s, k}=k_{r} \widehat{\boldsymbol{\psi}}_{r, k}+L_{\sigma} \boldsymbol{i}_{s, k}
\end{gathered}
$$

where $k_{r}=L_{m} / L_{r}, \tau_{r}=L_{r} / R_{r}$, and $L_{\sigma}=L_{s}-L_{m}^{2} / L_{r}$.

To this end, the expression of the $\boldsymbol{\psi}_{s}^{p}$ and $\boldsymbol{i}_{s}^{p}$ in discrete form can be defined as follows:

$$
\begin{gathered}
\boldsymbol{\psi}_{s, k+1}^{p}=\widehat{\boldsymbol{\psi}}_{s, k}+T\left(\boldsymbol{v}_{s, k}-R_{s} \boldsymbol{i}_{s, k}\right) \\
\boldsymbol{i}_{s, k+1}^{p}=\left(1-\frac{T}{\tau_{\sigma}}\right) \boldsymbol{i}_{s, k}+ \\
\frac{T}{\tau_{\sigma} R_{\sigma}}\left(k_{r}\left(\frac{1}{\tau_{r}}-j \omega_{r, k}\right) \widehat{\boldsymbol{\psi}}_{r, k}+\boldsymbol{v}_{s, k}\right)
\end{gathered}
$$

where $R_{\sigma}=R_{s}+k_{r}^{2} R_{r}$ and $\tau_{\sigma}=L_{\sigma} / R_{\sigma}$.

Using predicted $\boldsymbol{\psi}_{s}^{p}$ and $\boldsymbol{i}_{s}^{p}, \tau_{e}^{p}$ can be calculated as follows:

$$
\tau_{e, k+1}^{p}=\frac{3}{2} p_{p} \Im m\left(\boldsymbol{\psi}_{s, k+1}^{p} i_{s, k+1}^{p}\right)
$$




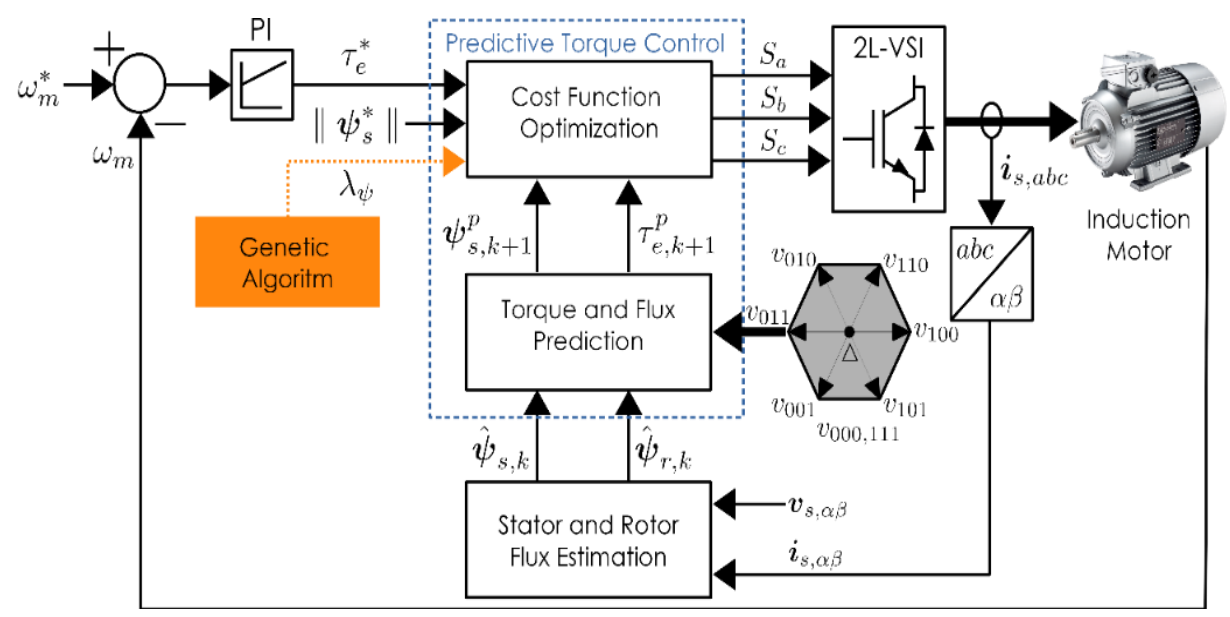

Figure 2. Optimized PTC-based IM drive

The cost function of the PTC given in Equation (13) consists of two components: torque error component and flux error component. In traditional PTC, the weighting factor of the torque component is assumed as one, whereas the weighting factor of the flux component $\left(\lambda_{\psi}\right)$ is higher than one. Also, one additional component $\left(I_{m}\right)$ protecting the IM from overcurrents can be included as in Equation (13). The definition of the $I_{m}$ is given in Equation (14).

$$
\begin{gathered}
g_{i}=\left|\tau_{e}^{*}-\tau_{e, k+1}^{p}\right|+\lambda_{\psi}|| \boldsymbol{\psi}_{s}^{*}|-| \boldsymbol{\psi}_{s, k+1}^{p}||+I_{m, k+1} \\
I_{m, k+1}= \begin{cases}0, & \text { if }\left|\boldsymbol{i}_{s, k+1}^{p}\right| \leq\left|i_{s, \max }\right| \\
\infty, & \text { if }\left|\boldsymbol{i}_{s, k+1}^{p}\right|>\left|i_{s, \max }\right|\end{cases}
\end{gathered}
$$

Table 1. GA Parameters

\begin{tabular}{llll}
\hline Parameter & Value & Parameter & Value \\
\hline Population Size & 30 & Crossover Rate & 0.8 \\
Maximum Gen. & 20 & Crossover Func. & Single Point \\
Lower Bound & 0.1 & Mutation Rate & 0.05 \\
Upper Bound & 200 & Mutation Func. & Uniform \\
\hline
\end{tabular}

\section{Metaheuristic optimization of predictive torque control}

In this section, the $\lambda_{\psi}$ is optimized by a GA through speed errors only. For this purpose, both PTC and GA have been implemented in Matlab R2016b. The parameters for the GA used in optimization are given in Table 1. The cost function of the GA is as follows:

$$
f_{\text {cost }}=\frac{1}{n} \sum_{i=1}^{n}\left(\omega_{m, i}^{*}-\omega_{m, i}\right)^{2}
$$

To eliminate the adverse effect of random behavior of meta-heuristic optimization algorithms, the optimization process has been repeated ten times. The statistics of the optimized parameter for all runs is shown as a boxplot in Figure 3. Among these optimized parameters, four different values (i.e., maximum value, median value, minimum value, and an outlier value) marked in Figure 3 have been selected to use in simulation studies. In this way, it is possible to show the effect of different WFs.

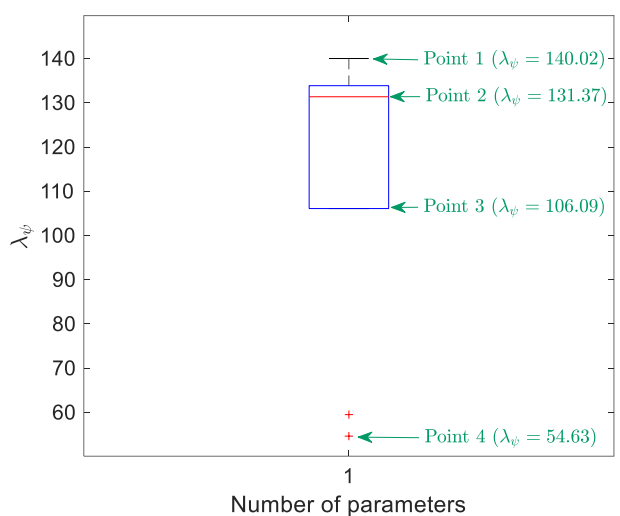

Figure 3. Boxplot representation of ten optimization results

\section{Results}

In simulation studies, a 3-phase squirrel cage type IM with the specifications in Table 2 is used. The speed controller is of PI-type and the sampling time is $50 \mu \mathrm{s}$. To test the optimized PTC, different operating conditions have been considered in simulation studies. To this end, the first test focuses on performance evaluation at low speeds, while the second test evaluates optimized PTCs at higher speeds. Both tests include the operations with and without load so that the proposed selection method can be evaluated in different operating conditions. The resulting control performances for both tests are shown in Figure 4 and 5, respectively.

Table 2. The specifications of the IM

\begin{tabular}{cccc}
\hline Parameter & Value & Parameter & Value \\
\hline$P$ & $3 \mathrm{~kW}$ & $R_{s}$ & $2.283 \Omega$ \\
$V$ & $380 \mathrm{~V}$ & $R_{r}$ & $2.133 \Omega$ \\
$I$ & $6.9 \mathrm{~A}$ & $L_{m}$ & $0.22 \mathrm{H}$ \\
$f$ & $50 \mathrm{~Hz}$ & $L_{s}$ & $0.2311 \mathrm{H}$ \\
$p_{p}$ & 2 & $L_{r}$ & $0.2311 \mathrm{H}$ \\
$n_{m}$ & $1430 \mathrm{r} / \mathrm{min}$ & $J_{t}$ & $0.0183 \mathrm{~kg} . \mathrm{m}^{2}$ \\
$\tau_{l}$ & $20 \mathrm{Nm}$ & $B_{t}$ & $0.001 \mathrm{~N} . \mathrm{m} . \mathrm{s}$ \\
\hline
\end{tabular}



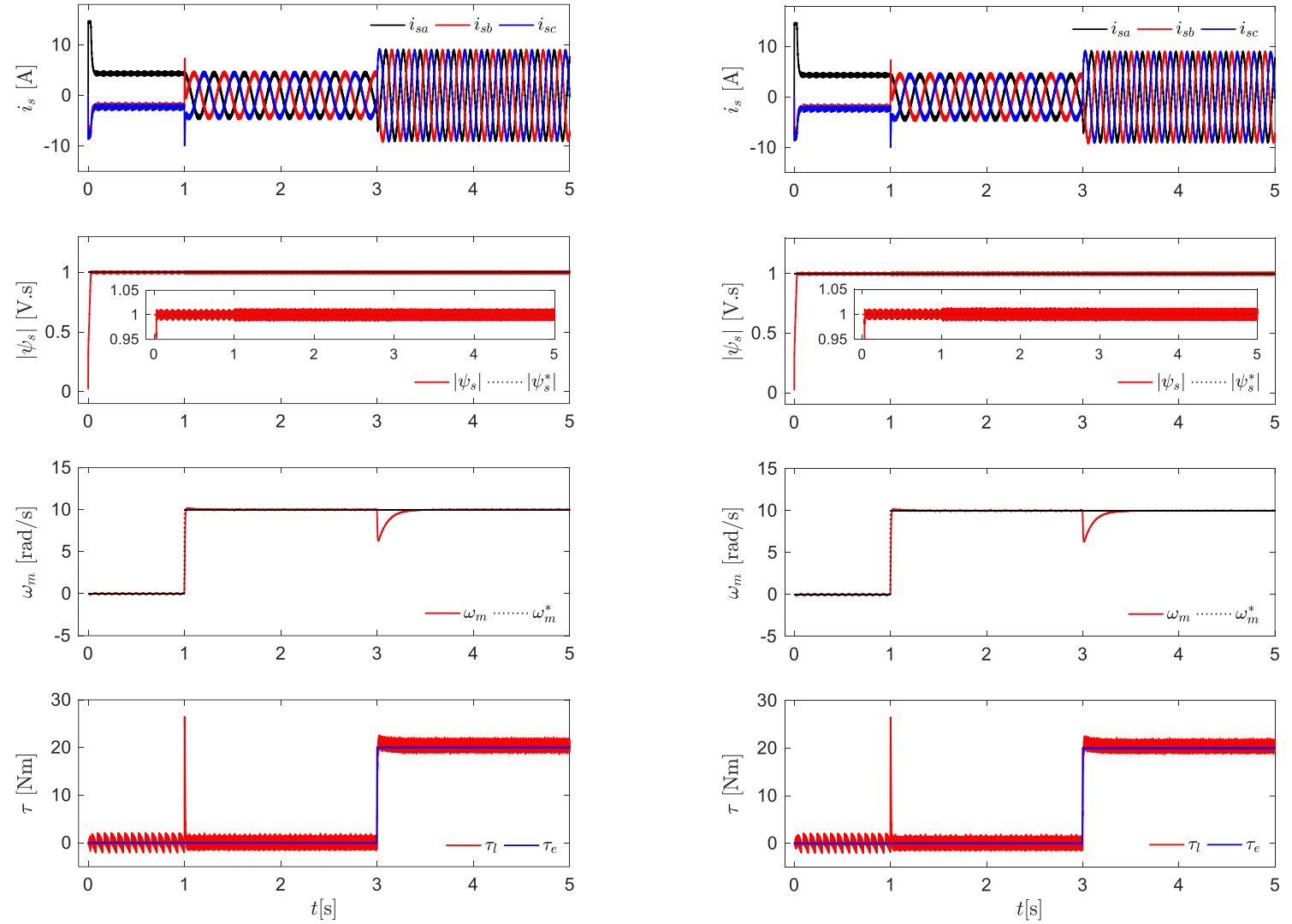

(a)

(b)
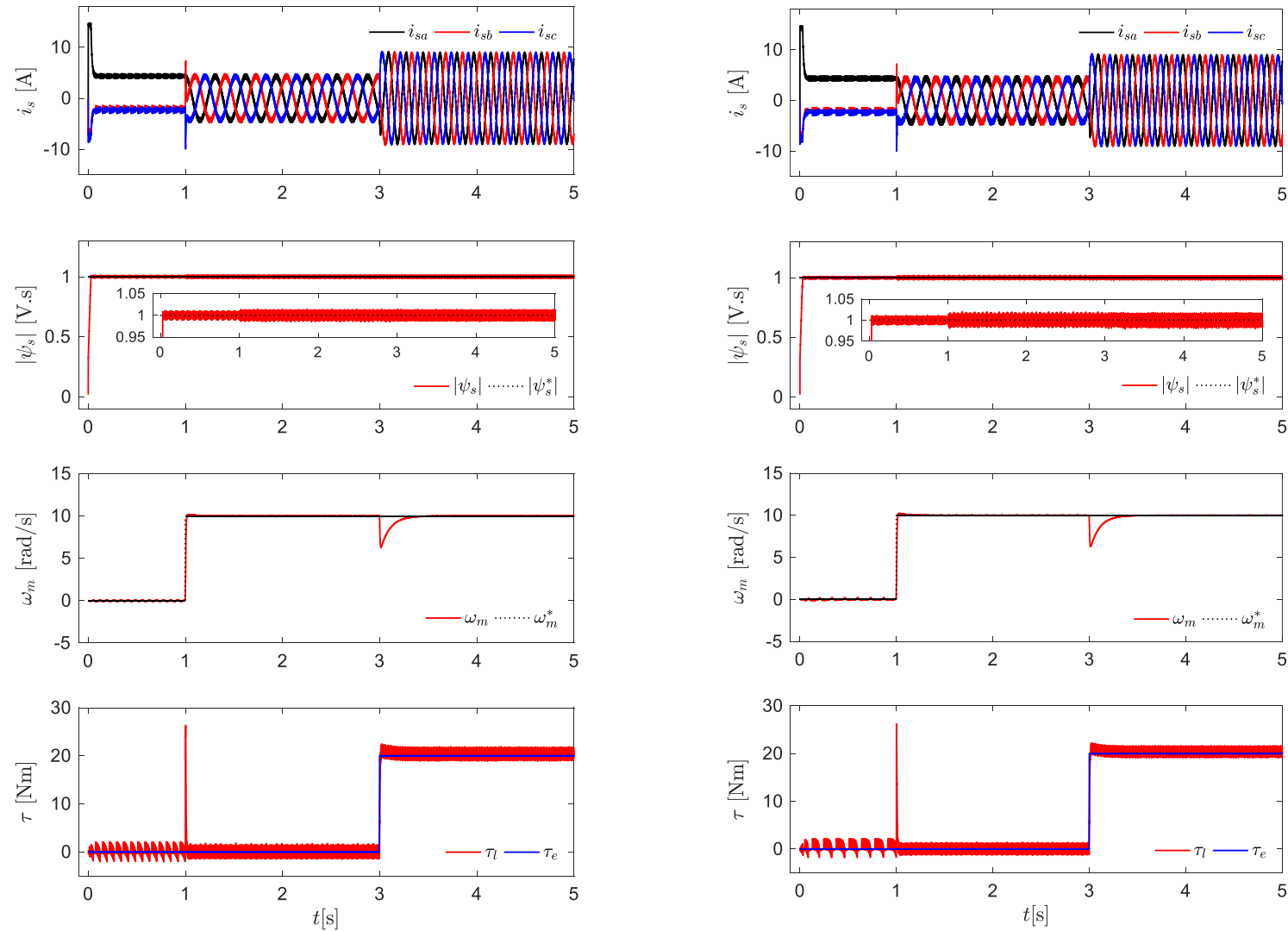

(c)

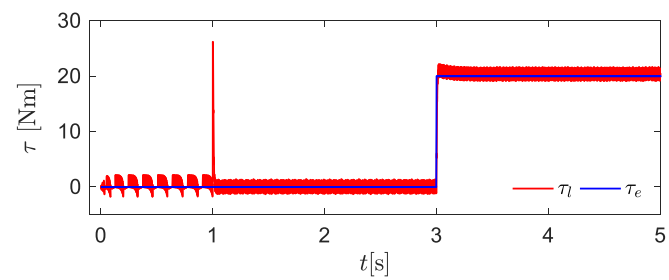

(d)

Figure 4. Control performance of the optimized PTC at $10 \mathrm{rad} / \mathrm{s}$ for a) Point 1 b) Point 2 c) Point 3 d) Point 4 

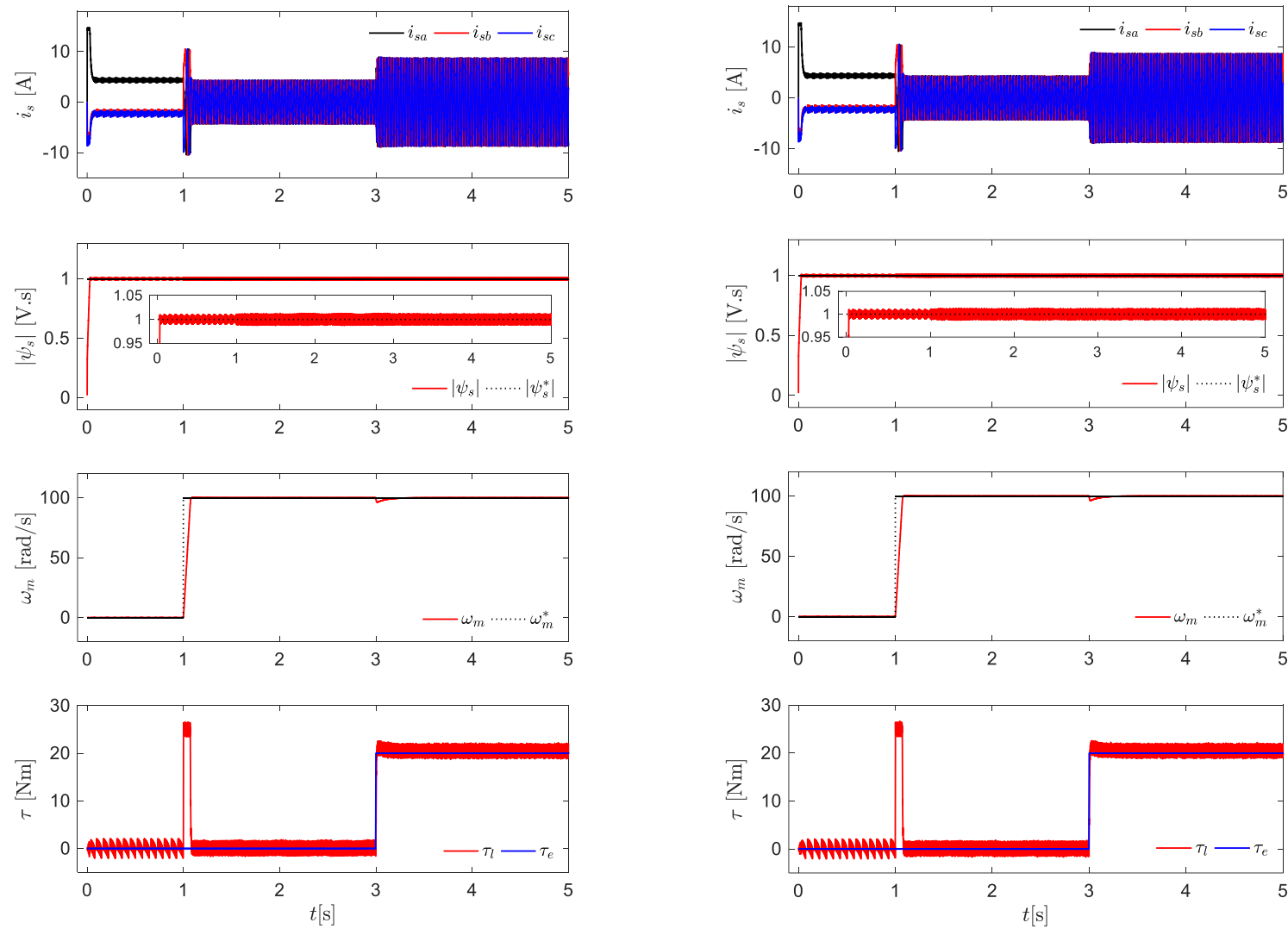

(a)

(b)
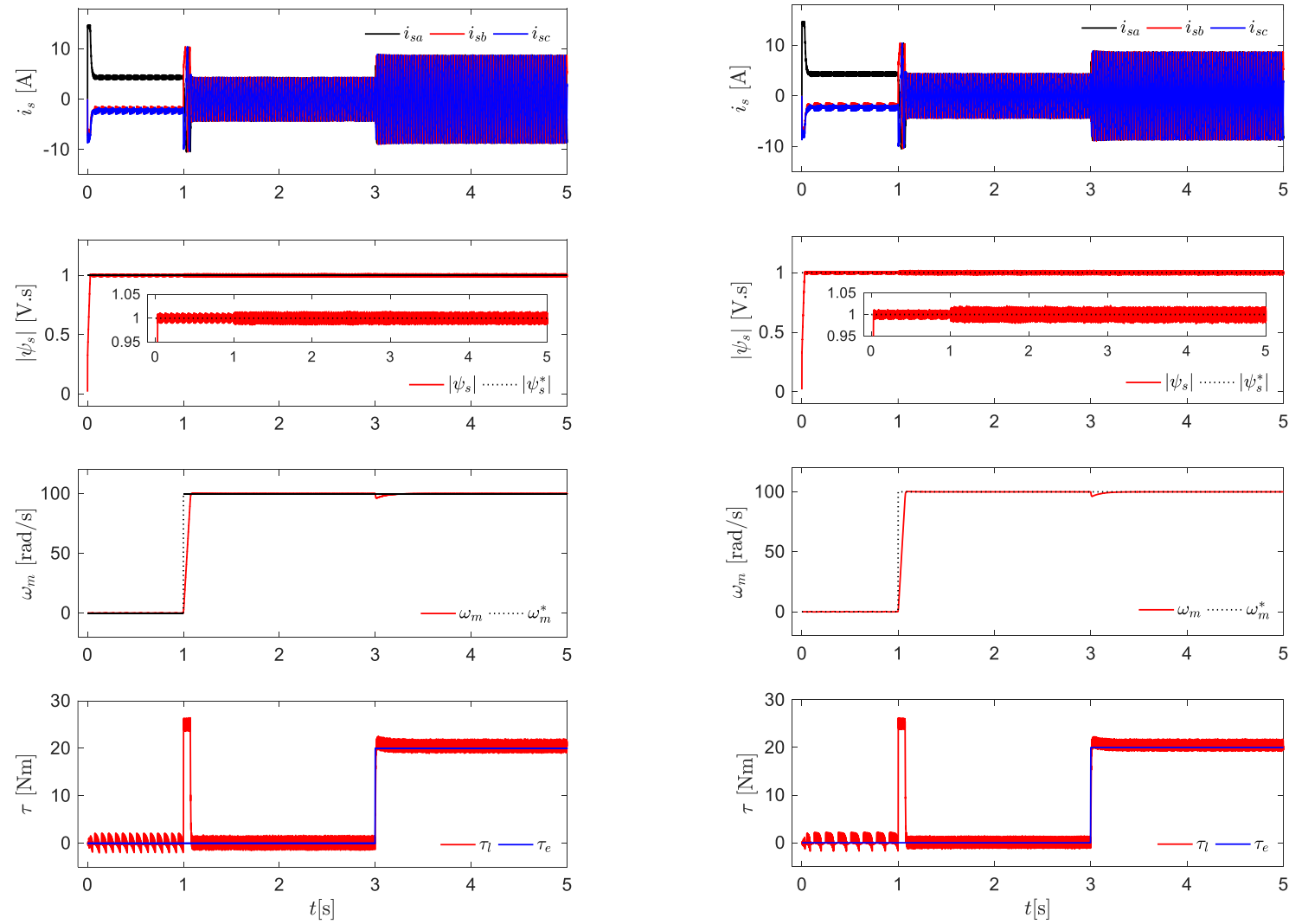

(c)

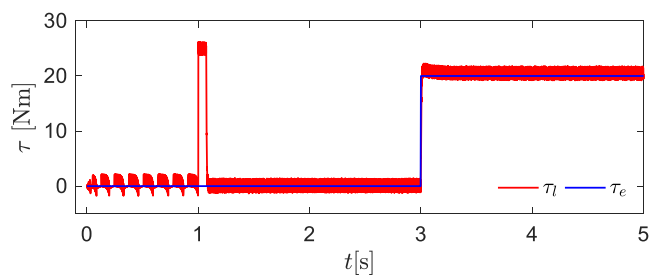

(d)

Figure 5. Control performance of the optimized PTC at $100 \mathrm{rad} / \mathrm{s}$ for a) Point $1 \mathrm{~b}$ ) Point 2 c) Point 3 d) Point 4 
Table 3. Statistics for Figure 4 and 5

\begin{tabular}{|c|c|c|c|c|c|c|}
\hline Speed & Load Condition & Point & $T_{\text {rip }}(\%)$ & $\psi_{\text {rip }}(\%)$ & THD $(\%)$ & $f_{\text {avg }}$ \\
\hline \multirow{8}{*}{$10 \mathrm{rad} / \mathrm{s}$} & \multirow{4}{*}{ No-Load } & 1 & 9.93 & 1.25 & 8.01 & $1.38 \mathrm{kHz}$ \\
\hline & & 2 & 9.53 & 1.31 & 8.02 & $1.42 \mathrm{kHz}$ \\
\hline & & 3 & 9.07 & 1.40 & 8.04 & $1.50 \mathrm{kHz}$ \\
\hline & & 4 & 7.12 & 1.97 & 8.80 & $1.89 \mathrm{kHz}$ \\
\hline & \multirow{4}{*}{$20 \mathrm{Nm}$} & 1 & 8.85 & 1.20 & 4.11 & $1.36 \mathrm{kHz}$ \\
\hline & & 2 & 8.58 & 1.25 & 4.09 & $3.49 \mathrm{kHz}$ \\
\hline & & 3 & 7.53 & 1.36 & 4.11 & $3.65 \mathrm{kHz}$ \\
\hline & & 4 & 6.24 & 1.82 & 4.53 & $4.58 \mathrm{kHz}$ \\
\hline \multirow{8}{*}{$100 \mathrm{rad} / \mathrm{s}$} & \multirow{4}{*}{ No Load } & 1 & 8.79 & 1.31 & 8.89 & $9.25 \mathrm{kHz}$ \\
\hline & & 2 & 8.77 & 1.34 & 8.95 & $9.33 \mathrm{kHz}$ \\
\hline & & 3 & 7.93 & 1.45 & 8.89 & $9.68 \mathrm{kHz}$ \\
\hline & & 4 & 6.82 & 2.05 & 9.57 & $10.85 \mathrm{kHz}$ \\
\hline & \multirow{4}{*}{$20 \mathrm{Nm}$} & 1 & 8.62 & 1.21 & 4.22 & $8.94 \mathrm{kHz}$ \\
\hline & & 2 & 8.50 & 1.27 & 4.19 & $8.94 \mathrm{kHz}$ \\
\hline & & 3 & 7.57 & 1.40 & 4.22 & $9.17 \mathrm{kHz}$ \\
\hline & & 4 & 6.71 & 1.90 & 4.68 & $9.69 \mathrm{kHz}$ \\
\hline
\end{tabular}

The percentage torque $\left(T_{\text {rip }}\right)$ and flux $\left(\psi_{\text {rip }}\right)$ ripples, total harmonic distortions (THDs) of the stator currents (phase $-a$ only), and average switching frequencies $\left(f_{\text {avg }}\right)$ have been calculated for the time intervals of $1.5 \leq t \leq 2.5 \mathrm{~s}$ and $3.5 \leq$ $t \leq 4.5 \mathrm{~s}$ of Figure 3 and 4 . These values can be found in Table 3.

Considering the control performances in Figure 3 and 4 and the statistics in Table 3, the following comments can be made:

- $\quad$ All optimized $\lambda_{\psi}$ values lead to adequate control performance as seen in Figure 3 and 4 . The question is which one is better?

- $\quad$ For all test points considered, larger $\lambda_{\psi}$ values result in a reduction in flux ripples, total harmonic distortions and average switching frequency but an increase in torque ripples. In this respect, the selection is application-dependent. Larger values should be selected to reduce torque ripples while lower values should be chosen to reduce the flux ripples, average switching frequency, total current distortions.

- $\quad$ Point 3 provides a trade-off between torque ripples and flux ripples/average switching frequency/total current distortions.

\section{Conclusion}

In this paper, the WF in PTC has been optimized by a GA through speed errors only and the optimized PTC has been tested by simulation studies. To show the effectiveness of the optimized PTC, different operating conditions have been considered in simulation studies. The results demonstrate that the proposed method is an effective solution in determining WFs with a simplification of the optimization problem. It also reveals the relationships between the WF and torque ripples/flux ripples/average switching frequency/total harmonics distortions. However, the number of WFs has been limited to one in this paper. Future studies will focus on the optimization of more WFs associated with additional control objectives.

\section{Conflict of Interest}

The author has no conflicts of interest to declare.

Similarity (iThenticate): $\% 15$

\section{Kaynaklar}

[1] J. Rodriguez, R. M. Kennel, J. R. Espinoza, M. Trincado, C. A. Silva, and C. A. Rojas, Highperformance control strategies for electrical drives: an experimental assessment. IEEE Trans. Ind. Electron., 59(2), 812-820, 2012. https://doi.org/10. 1109/ TIE. 2011. 2158778

[2] F. Wang, Z. Zhang, X. Mei, J. Rodríguez, and R. Kennel, Advanced control strategies of induction machine: field oriented control, direct torque control and model predictive control. Energies, 11(1), 120, 2018. https://doi.org/10.3390/en11010120.

[3] F. Wang, S. Li, X. Mei, W. Xie, J. Rodríguez, and R. M. Kennel, Model-based predictive direct control strategies for electrical drives: An experimental evaluation of PTC and PCC methods. IEEE Trans. Ind. Inform., 11(3), 671-681, 2015. https://doi.org/10.1109/ TII.2015.2423154.

[4] S. Kouro, P. Cortes, R. Vargas, U. Ammann, and J. Rodriguez, Model predictive control-a simple and powerful method to control power converters. IEEE Trans. Ind. Electron., 56(6), 1826-1838, 2009. https:// doi.org/10.1109/TIE.2008.2008349.

[5] M. Mamdouh, M. A. Abido, and Z. Hamouz, Weighting factor selection techniques for predictive torque control of induction motor drives: A comparison study. Arab. J. Sci. Eng., 43(2), 433-445, 2018. https:// doi.org/10.1007/s13369-017-2842-2.

[6] P. R. U. Guazzelli, W. C. de Andrade Pereira, C. M. R. de Oliveira, A. G. de Castro, and M. L. de Aguiar, Weighting factors optimization of predictive torque control of induction motor by multiobjective genetic algorithm. IEEE Trans. Power Electron., 34(7), 66286638, 2019. https://doi.org/10.1109/TPEL.2018.283 4304. 
[7] M. H. Arshad, M. A. Abido, A. Salem, and A. H. Elsayed, Weighting Factors Optimization of Model Predictive Torque Control of Induction Motor Using NSGA-II with TOPSIS Decision Making. IEEE Access, 7, 177595-177606, 2019. https://doi.org/10.11 09/ACCESS.2019.2958415.

[8] S. A. Davari, V. Nekoukar, C. Garcia, and J. Rodriguez, Online weighting factor optimization by simplified simulated annealing for finite set predictive control. IEEE Trans. Ind. Inform., 17(1), 31-40, 2021. https://do i .org/10.1109/TII.2020.2981039.

[9] F. Wang, H. Xie, Q. Chen, S. A. Davari, J. Rodriguez, and R. Kennel, Parallel predictive torque control for induction machines without weighting factors. IEEE Trans. Power Electron., 35(2), 1779-1788, 2020. https ://doi.org/10.1109/TPEL.2019.2922312.

[10] C. A. Rojas, J. Rodriguez, F. Villarroel, J. R. Espinoza, C. A. Silva, and M. Trincado, Predictive torque and flux control without weighting factors. IEEE Trans. Ind. Electron., 60(2), 681-690, 2013. https://doi.org/10 $.1109 /$ TIE.2012.2206344.

[11] S. A. Davari, M. Norambuena, V. Nekoukar, C. Garcia, and J. Rodriguez, Even-Handed sequential predictive torque and flux control. IEEE Trans. Ind. Electron., 67(9), 7334-7342, 2020. https://doi.org/10.1109/TIE. 2019. 2945274.
[12] V. P. Muddineni, S. R. Sandepudi, and A. K. Bonala, Finite control set predictive torque control for induction motor drive with simplified weighting factor selection using TOPSIS method. IET Electr. Power Appl., 11(5), 749-760, 2017. https://doi.org/10.1049/iet-epa.2016. 0503.

[13] V. P. Muddineni, A. K. Bonala, and S. R. Sandepudi, Grey relational analysis-based objective function optimization for predictive torque control of induction machine. IEEE Trans. Ind. Appl., 57(1), 835-844, 2021 . https://doi.org/10.1109/TIA.2020.3037875.

[14] Y. Zhang and H. Yang, Model-Predictive flux control of induction motor drives with switching instant optimization. IEEE Trans. Energy Convers., 30(3), 1113-1122, 2015. https://doi.org/10.1109/TEC.2015.2 423692.

[15] C. A. Rojas, J. R. Rodriguez, S. Kouro, and F. Villarroel, Multiobjective fuzzy-decision-making predictive torque control for an induction motor drive. IEEE Trans. Power Electron., 32(8), 6245-6260, 2017. https://doi.org/10.1109/TPEL.2016.2619378.

[16] E. Zerdali and M. Barut, The comparisons of optimized extended kalman filters for speed-sensorless control of induction motors. IEEE Trans. Ind. Electron., 64(6), 4340-4351, 2017. https://doi.org/ 10.1109/TIE.2017.2 674579 . 